\title{
The Effect Of Lavender Aromatheraphy On Decreasing Of Perineum Paint Pain in Breast Mothers
}

\author{
Anita Indra Afriani' ${ }^{1}$, Deny Rahmawati ${ }^{2}$
}

1,2 STIKes Karya Husada Semarang

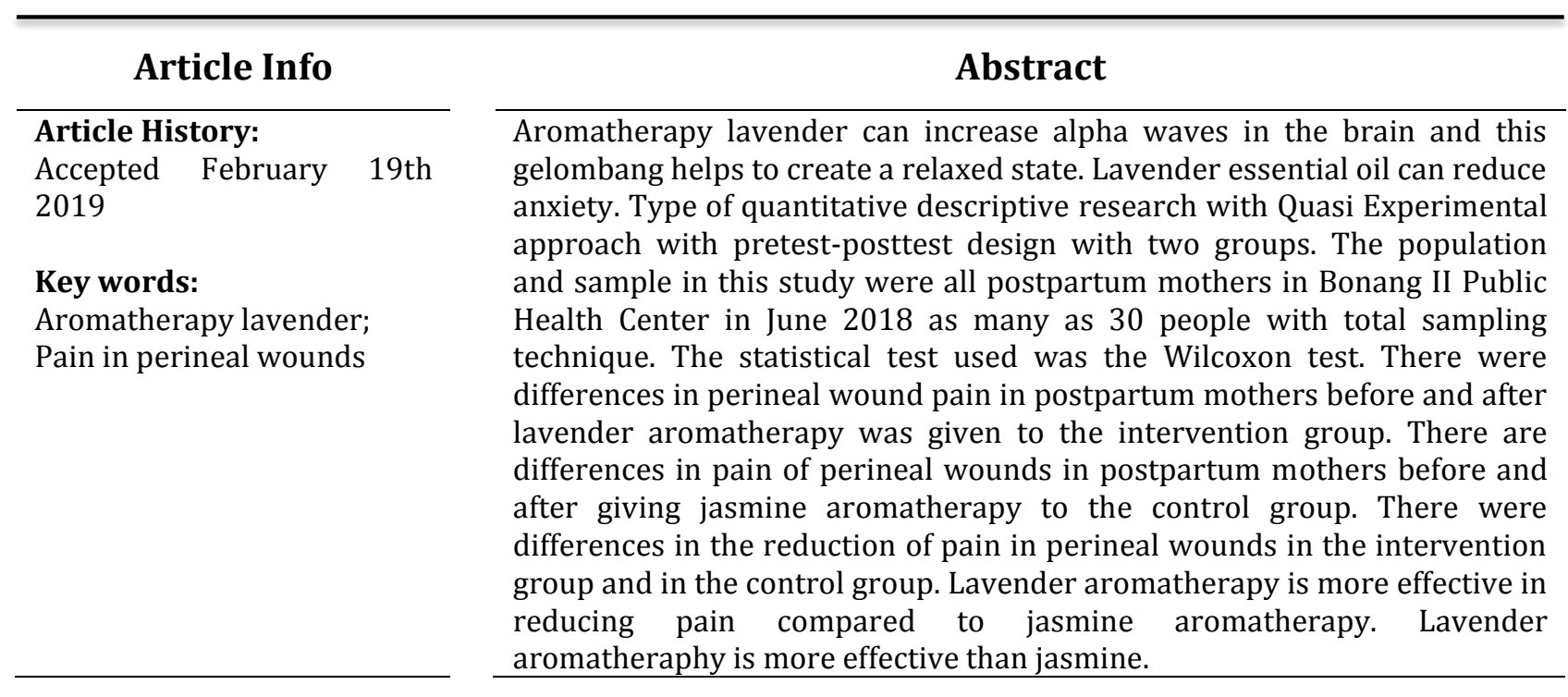

\section{PENDAHULUAN}

Nyeri pasca persalinan adalah nyeri perineum yang merupakan hal yang fisiologis pada ibu post partum, akan tetapi nyeri ini memengaruhi kemampuan wanita untuk mobilisasi sehingga dapat menimbulkan komplikasi seperti perdarahan post partum. Di Rumah Sakit Royal Victoria Australia dilaporkan bahwa 90\% wanita mengalami nyeri perineum, Nyeri dirasakan ketika berjalan 933\%), duduk (39\%), dan tidur (45\%) (P.A \& A.G, 2008)..

Banyak cara yang dapat digunakan dalam menghilangkan rasa sakit saat persalinan, cara tersebut antara lain dengan tindakan farmakologis dan tindakan non farmakologis. Tindakan farmakologis yang digunakan antara lain penggunaan analgesik suntikan epidural, intracthecal labor analgesik (ILA), dll. Tindakan tindakan tersebut hampir semua mempunyai efek samping pada ibu dan juga janin (Wong, 2009)..

Berdasarkan alasan tersebut diatas, tindakan nonfarmakologis dalam manajemen nyeri merupakan trend baru yang dapat dikembangkan dan merupakan metode alternatif dapat digunakan pada ibu untuk mengurangi nyeri persalinan. Metode non farmakologis dapat memberikan efek relaksasi kepada pasien dan dapat membantu meringankan 
ketegangan otot dan emosi serta dapat mengurangi nyeri persalinan (Astuti, 2009).. Metode nonfarmakologi juga dapat meningkatkan kepuasan selama persalinan, karena ibu dapat mengontrol perasaannya dan kekuatannya. Relaksasi, teknik pernapasan, pergerakan dan perubahan posisi, massage, hidroterapi, terapi panas/dingin, musik, guided imagery, akupresur, aromaterapi merupakan beberapa teknik nonfarmakologi yang dapat meningkatkan kenyamanan ibu saat bersalin dan mempunyai pengaruh pada koping yang efektif terhadap pengalaman persalinan (Arifin, 2008)..

Aromaterapi lavender dapat meningkatkan gelombang alfa di dalam otak dan gelomabang inilah yang membantu untuk menciptakan keadaan yang rileks. Minyak esensial lavender dapat mengurangi kecemasan. Pemijatan dengan menggunakan lavender menunjukkan mengurangi tingkat kecemasan pada pasien intensif, dan dapat menurunkan kecemasan pada pasien hemodialisa. Wanita yang sedang menjalani persalinan, berendam dengan menggunakan minyak lavender dapat mengurangi rasa nyeri pada daerah perineum dan mengurangi kegelisahan (Hale, 2008)..

Menurut data dari Puskesmas Bonang II, jumlah ibu bersalin dalam tahun 2017 adalah 845 jiwa, dan menurut hasil wawancara dengan salah satu bidan menunjukkan dari 760 ibu bersalin 80\% mengalami luka perineum baik secara alami maupun dengan episiotomi dan semua dijahit. Sebagian ibu yang mengalami luka perineum mengeluh sakit terutama bagi ibu primipara. Dan dalam mengurangi rasa sakit akibat luka perineum sebagian menggunakan antiseptik/betadin belum ada yang menggunakan dengan aromaterai. Oleh karena itu peneliti ingin mengetahui apakah ada pengaruh aromaterapi lavender terhadap penurunan rasa nyeri luka perineum pada ibu nifas di wilayah Puskesmas Bonang II Kabupaten Demak Tahun 2018.

\section{METODE PENELITIAN}

Jenis Penelitian ini yaitu kuantitatif , Desain yang digunakan dalam penelitian ini adalah dengan menggunakan rancangan Quasi Eksperimental dengan rancangan two group pretest-postest with control design (Notoatmodjo, 2010).. Rancangan penelitian ini secara skematis dapat dituliskan sebagai berikut :

Kelompok Aromaterapi lavender intervensi Kelompok kontrol

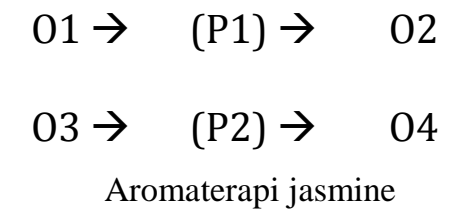

Gambar 1

Desain Penelitian

Waktu penelitian dilakukan sampai bulan Agustus 2018 di Wilayah Puskesmas Bonang II Kabupaten Demak. Populasi dan sampel dalam penelitian ini adalah semua ibu nifas yang ada di wilayah Puskesmas Bonang II pada bulan Juni 2018 sebanyak 30 orang (15 orang kelompok intervensi dan 15 orang kelompok kontrol). Dengan kriteria inklusi dan eksklusi ibu melahirkan di Puskesmas Bonang II secara pervaginam, 2 jam postpartum dengan riwayat primigravida. Teknik sampling yang dipakai dalam penelitian ini total sampling yang mana pengambilan sampel pada seluruh populasi. Instrument penelitian menggunakan aromaterapi lavender dan cheklis Numerical Rating Scale (NRS).

Analisis data univariate menggunakan mean, median, modus dan standar deviasi. Analisis bivariate uji normalitas menggunakan Shapiro Wilk untuk mengetahui perbedaan penurunan rasa nyeri luka perineum dan pada ibu nifas sebelum dan sesudah menggunakan aromaterapi menggunakan uji Paired Samples T-Test (bila distribusi data normal), atau Wilcoxon test (bila distribusi data tidak normal). 
HASIL

\section{Perbedaan Aromaterapi Lavender dan Jasmine terhadap Penurunan Rasa Nyeri Luka Perineum pada Ibu Nifas}

Tabel 1

Nilai rata-rata rasa nyeri sebelum dan sesudah pemberian aromaterapi lavender

\begin{tabular}{lcc}
\hline $\begin{array}{c}\text { Aromaterapi } \\
\text { Lavender }\end{array}$ & Means & $P$ \\
\hline $\begin{array}{l}\text { Lavender } \\
\text { Sebelum }\end{array}$ & 3,2 & $0,001^{*}$ \\
Sesudah & 2,3 & \\
\hline Jasmine & & \\
Sebelum & 3,5 & $0,007^{*}$ \\
Sesudah & 2,9 & \\
\hline
\end{tabular}

${ }^{*}$ Wilcoxon

Terdapat penurunan rasa nyeri perineum antara sebelum dan sesudah, yaitu sebesar 1,0 dimana sebelum aromaterpai lavender nilai rata-rata sebesar 3,2 dan nilai rata-rata sesudah aromaterpai lavender sebesar 2,2. Dari uji normalitas didapatkan distribusi data tidak normal sehingga menggunakan uji wilcoxon sign diperoleh nilai $\mathrm{p}=0,001$, karena nilai $\mathrm{p}<0,05$ berati ada perbedaan rasa nyeri sebelum dan sesudah diberikan aromaterapi lavender.

Terdapat penurunan rasa nyeri perineum antara sebelum dan sesudah, yaitu sebesar 0,6 dimana sebelum aromaterpai jasmine nilai rata-rata sebesar 3,5 dan nilai rata-rata sesudah aromaterpai jasmine sebesar 2,9. Dari uji normalitas didapatkan distribusi data tidak normal sehingga menggunakan uji wilcoxon sign diperoleh nilai $\mathrm{p}=0,007$, karena nilai $\mathrm{p}<0,05$ berati ada perbedaan rasa nyeri sebelum dan sesudah diberikan aromaterapi jasmine.

\section{Pengaruh Aromaterapi Lavender terhadap Penurunan Rasa Nyeri Luka Perineum pada Ibu Nifas.}

Tabel 2

Nilai rata-rata rasa nyeri sesudah pemberian aromaterapi lavender dan jasmine.

\begin{tabular}{lcc}
\hline Aromaterapi & Means sesudah & $P$ \\
\cline { 1 - 2 } 1. Lavender & 2,2 & \multirow{2}{*}{0,006} \\
\cline { 1 - 1 } 2. Jasmine & 2,9 & \\
\hline${ }^{*}$ mann-whitney test &
\end{tabular}

Hasil penelitian menunjukkan bahwa nilai rata-rata sesudah aromaterapi lavender 2,2, nilai rata-rata sesudah aromaterapi jasmine 2,9. Sebelum dilakukan uji perbedaan penurunan rasa nyeri luka perineum pada kelompok intervensi dan kelompok kontrol terlebih dahulu dilakukan uji normalitas data. Dari uji normalitas didapatkan distribusi data tidak normal sehingga menggunakan uji mann-whitney test diperoleh nilai $\mathrm{p}=0,006$, karena nilai $\mathrm{p}<$ 0,05 berati ada perbedaan penurunan rasa nyeri luka perineum pada kelompok intervensi dan kelompok kontrol.

Dari hasil penelitian diketahui bahwa penurunan skala rata-rata aromaterapi lavender 1,0, sedangkan penurunan aromaterapi jasmine 0,6. Hal ini berarti bahwa aromaterapi lavender lebih efektif menurunkan rasa nyeri dibandingkan dengan aromaterapi jasmine.

\section{PEMBAHASAN}

Hasil penelitian menunjukkan bahwa terdapat perbedaan penurunan rasa nyeri luka perineum pada kelompok intervensi dan kelompok kontrol. Hasil penelitian juga dapat diketahui bahwa penurunan nilai rata-rata aromaterapi lavender lebih banyak dari pada aromaterapi jasmine. Hal ini berarti bahwa aromaterapi dengan lavender lebih cepat menurunkan rasa nyeri jika dibandingkan dengan aromaterapi dengan jasmin. 
Hal ini sesuai dengan hasil penelitian (Turlina, 2017). yang menunjukkan bahwa terapi esensial minyak lavender berpengaruh secara positif terhadap kecemasan dan insomnia serta mengontrol rasa sakit. Aroma terapi (aroma lavender) merupakan salah satu metode yang bisa digunakan untuk mengurangi penyebab dari rasa nyeri. Aroma yang berasal dari aromaterapi bekerja mempengaruhi emosi seseorang dengan limbic (lewat sistem olfaktori) dan pusat emosi otak. Bau yang berasal dari aromaterapi diterimah oleh reseptor dihidung kemudian dikirimkan ke bagian medulla spinalis di otak, didalam hal ini kemudian akan meningkatkan gelombang-gelombang alfa diotak dan gelombang-gelombang alfa inilah yang membantu untuk merasa relaksasi.

Aromaterapi lavender mempunyai efek menenangkan. Lavender dapat memberikan ketenangan, keseimbangan, rasa nyaman, rasa keterbukaan dan keyakinan. Disamping itu lavender juga dapat mengurangi rasa tertekan, stress, rasa sakit, emosi yang tidak seimbang, histeria, rasa frustasi dan kepanikan. Lavender dapat bermanfaat untuk mengurangi rasa nyeri, dan dapat memberikan relaksasi. Berbeda dengan aromaterapi Jasmine merupakan jenis aroma yang sanggup menciptakan suasana romantis. Namun, jangan digunakan terlalu banyak. Sebab, aroma kuat bunga melati justru membuat udara menjadi tidak segar, bahkan mungkin sedikit menyeramkan (Hutasoit, 2010)..

Namun tidak semua pasien yang mendapatkan Aromaterapi mampu mengatasi nyeri persalinan dengan baik. Hal ini dapat disebabkan oleh beberapa faktor seperti kurangnya individu yang mendukung, dan lingkungan yang mungkin tidak dapat diterima oleh ibu bersalin. Lingkungan dan kehadiran dukungan keluarga juga dapat mempengaruhi nyeri seseorang. Pada beberapa pasien yang mengalami nyeri sering kali tergantung pada anggota keluarga atau teman dekat untuk memperoleh dukungan, bantuan perlindungan. Walaupun nyeri tetap terasa, tetapi kehadiran orang yang dicintai akan dapat meminimalkan rasa kecemasan dan ketakutan. Apabila keluarga atau teman tidak ada seringkali membuat nyeri pasien tersebut semakin tertekan (P.A \& A.G, 2008)..

Aromaterapi adalah terapi yang menggunakan essensial oil atau sari minyak murni untuk membantu memperbaiki atau menjaga kesehatan, membangkitkan semangat, menyegarkan serta membangkitkan jiwa raga. Aromaterapi mempunyai efek yang positif karena diketahui bahwa aroma yang segar, harum merangsang sensori, reseptor dan pada akhirnya mempengaruhi organ yang lainnya sehingga dapat menimbulkan efek kuat terhadap emosi (Hutasoit, 2010)..

\section{SIMPULAN}

Terdapat perbedaan nyeri luka perineum pada ibu nifas di wilayah Puskesmas Bonang II sebelum dan sesudah diberikan aromaterapi lavender pada kelompok intervensi. Terdapat perbedaan nyeri luka perineum pada ibu nifas di wilayah Puskesmas Bonang II sebelum dan sesudah dengan diberikan aromaterapi jasmine pada kelompok control. Aromaterapi lavender lebih efektif menurunkan rasa nyeri dibandingkan dengan aromaterapi jasmine.

\section{REFERENSI}

Arifin, L. (2008). Teknik Akupresur Pada Persalinan. 20 Februari 2018.

Astuti, R. (2009). Pengaruh aromaterapi terhadap nyeri persalinan kala 1 di bidan praktik swasta kecamatan Polokarto. Universitas Jenderal Soedirman.

Hale, G. (2008). Lavender - nature's aid to stress relief.

Hutasoit, A. (2010). Aromatherapy untuk Pemula. Jakarta: PT Gramedia Pustaka.

Notoatmodjo, S. (2010). Metodologi Penelitian Kesehatan. Jakarta: Rineka Cipta. 
P.A, P., \& A.G, P. (2008). Buku Ajar Fundamental Keperawatan Volume2. Jakarta: EGC.

Turlina, L. (2017). Pengaruh Pemberian Aromaterapi Lavender Terhadap Penurunan Tingkat Nyeri Pada Ibu Bersalin Kala I Fase Aktif di BPM Ny. Margelina, Amd. Keb Desa Supenuh Kecamatan Sugio Kabupaten Lamonga. STIKES Muhammadiyah Lamongan.

Wong, D. L. (2009). Pedoman Klinis Keperawatan Pediatrik. Jakarta: EGC.

Arifin, L. (2008). Teknik Akupresur Pada Persalinan. 20 Februari 2018.

Astuti, R. (2009). Pengaruh aromaterapi terhadap nyeri persalinan kala 1 di bidan praktik swasta kecamatan Polokarto. Universitas Jenderal Soedirman.
Hale, G. (2008). Lavender - nature's aid to stress relief.

Hutasoit, A. (2010). Aromatherapy untuk Pemula. Jakarta: PT Gramedia Pustaka.

Notoatmodjo, S. (2010). Metodologi Penelitian Kesehatan. Jakarta: Rineka Cipta.

P.A, P., \& A.G, P. (2008). Buku Ajar Fundamental Keperawatan Volume2. Jakarta: EGC.

Turlina, L. (2017). Pengaruh Pemberian Aromaterapi Lavender Terhadap Penurunan Tingkat Nyeri Pada Ibu Bersalin Kala I Fase Aktif di BPM Ny. Margelina, Amd. Keb Desa Supenuh Kecamatan Sugio Kabupaten Lamonga. STIKES Muhammadiyah Lamongan.

Wong, D. L. (2009). Pedoman Klinis Keperawatan Pediatrik. Jakarta: EGC. 